cussed by A. A. Demel (University of Utrecht) who reported that the amino terminal region of the protein seems to interact preferentially with lipids as this region is resistant to trypsin added to the subphase.

On the second day J. A. Lucy (Royal Free Hospital School of Medicine, London) drew attention to the possible role of increased lipid fluidity in membrane fusion. C. A. Pasternak (University of Oxford) then described experiments on membrane leakiness (not lysis) which may be an initial stage in virus-induced cell fusion; he also ventured the opinion that enzymes are not involved in this action of viruses. $K$. Simons (University of Helsinki) presented findings on the membrane glycoproteins of Semliki forest virus which resemble glycophorin in projecting right through the membrane. Considerable discussion was aroused by his intriguing proposal that release of virus by budding through the plasma membrane may involve recognition and interaction of nucleocapsid proteins with the cytoplasmically-exposed segments of these glycoproteins in the membranes of infected cells.

S. C. Kinsky (Washington University, St Louis) reported important studies on liposomes which he had rendered immunogenic by incorporating DNPcoupled, N-substituted derivatives of phosphatidylethanolamine. Appropriately substituted phospholipids thus seem potentially valuable in immunological studies on haptens: they may also be useful in the radioimmunoassay of drugs. Another investigation on liposomes was described by B. E. Ryman (Charing Cross Hospital Medical School, London) who has encapsulated enzymes within liposomes (of potential use in inborn errors of metabolism), and who is applying encapsulation to drugs, for example, 5-flourouracil, as this may permit the tissue specific application of relatively small doses of drugs.

Lysolecithin was a recurring topic, and there were discussions of whether or not small quantities might be involved in virus-induced cell fusion, of its acylation with unsaturated fatty acids in thymus cells stimulated by concanavalin $\mathrm{A}$, its possible role in cellular junctions and its facilitation of concanavalin A-induced agglutination in chicken erythrocytes during which $\mathrm{H}$. Fischer and his colleagues (Max-Planck Institute, Freiburg) made several contributions.

A lively exchange centred around the relevance of Mitchell's hypothesis in the transport of galactosides, amino acids and other molecules across membrane vesicles prepared from Escherichia coli that is coupled to the oxidation of Dlactate (H. R. Kaback, Roche, New Jersey; W. R. Konings, Haren, Nether- lands). Finally the mode of action of antibiotics on membranes, which seems still to be a very open question, was pursued by B. Deuticke (Technical High School, Aachen) who concluded that the presence of proteins scarcely modifies the action of these drugs on the lipid components of membranes, and by $\mathrm{B}$. de Kruyff (University of Utrecht) who discussed the formation of some interesting, albeit speculative, molecular complexes of polyenes with cholesterol in relation to their biological activity.

The meeting was sponsored by $\mathrm{Dr}$ Karl C. Thomae, Biberach/Riss, subsidiary to C. H. Boehringer, Ingelheim and was organised by L. L. van Deenen (University of Utrecht) with H. Schroeder (Thomae).

\section{Is the bass on the decline?}

\section{from our}

\section{Marine Vertebrate Correspondent}

THE bass (Dicentrarchus labrax) is a well known species to the sea angler; it is highly rated as a fighting fish, it grows to a fair weight, and has a relatively palatable flesh. In British waters it is widely distributed, but common only in the south and south-west, although it occurs as far north as Scotland where especially in the north-east it is rare. Until recently, however, its biology was virtually unknown; there were no data on its ageing and growth, little was known about its food, and the only knowledge of its spawning habits and early life was derived from elementary observations. The value of the bass to anglers first prompted research by staff of the Inland Fisheries Trust. Dublin who contributed to knowledge of the bass's biology in Irish waters (Kennedy and Fitzmaurice, J. mar. biol. Ass. U.K., 52, 557-597; 1972). Knowledge of this fish has now been extended in a report by Holden and Williams on dynamics of bass in English waters (J. mar. biol. Ass. U.K., 54, 91-107; 1974).

Holden and Williams's study was initiated by the concern expressed by angling bodies at the apparent decline in bass populations in English waters. A programme of tagging was begun with the aid of members of the National Federation of Sea Anglers, in which anglers tagged 954 bass in 1970 and 1971 mainly on the coast of Devon. Of these fish, 59 were recaptured, most (45) within $16 \mathrm{~km}$ of their release point and the majority (44) within the year of tagging. The exceptions, however, show that there were long-range movements, some of them over an extended period, the longest being 1,066 days at liberty. Most of the fish represented by returns had evidently made coastwise migrations, although one fish tagged on the South Devon coast was captured after 222 days in mid-Channel to the west of the Channel Isles.

On the basis of these tagging returns the authors suggest that the life history of bass in English waters falls into two phases. The first is the nursery stage when young fish of about $10 \mathrm{~cm}$ length enter estuaries in which they stay for 1 or 2 years, leaving usually as 3-yearold fish. The second phase is one of greater mobility when, as adult fish, they migrate coastwise and even offshore, possibly seasonally.

This synthesis of the first years agrees with the results of Kennedy and Fitzmaurice who also found young bass to live in estuaries, creeks and lagoons, but concluded that mature bass do not make extensive migrations. The different conclusions of Holden and Williams may be due to the fact that the Irish tagging was confined to the southern coasts of Ireland where bass are abundant and present all year round. A substantial part of the tagging effort of Holden and Williams was expended in similar areas of south-west England, however, and the data in confirmation of their theory amount to only 12 returned tags, of which only 6 were of distant migrations. In support of this rather slender data they cite communicated information from another source of three bass tagged off Anglesey which were recovered in Cornwall and Devon, but of this critical evidence no further information is advanced.

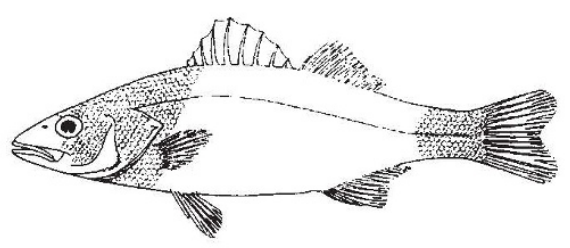

Dicentrarchus labrax.

The apparent contradiction between the conclusions of the two groups is important. If Kennedy and Fitzmaurice are correct in assuming that the bass populations are mainly sedentary, then heavy fishing could quickly lead to severe local depletion of the stock. Conversely, if Holden and Williams's conclusions are accepted the stock of bass is at least national, and heavier exploitation can be permitted locally without undue damage. It is unfortunate that in this critical area there is conflict of opinion and little data from which to draw conclusions.

With regard to the alleged decline in bass fishing, both pairs of authors consider the cause to be the failure of successive year-classes caused ultimately by climatic changes. Holden and Williams even venture to predict that if present climatic trends continue, bass could possibly become a rare species even in southern British waters. 